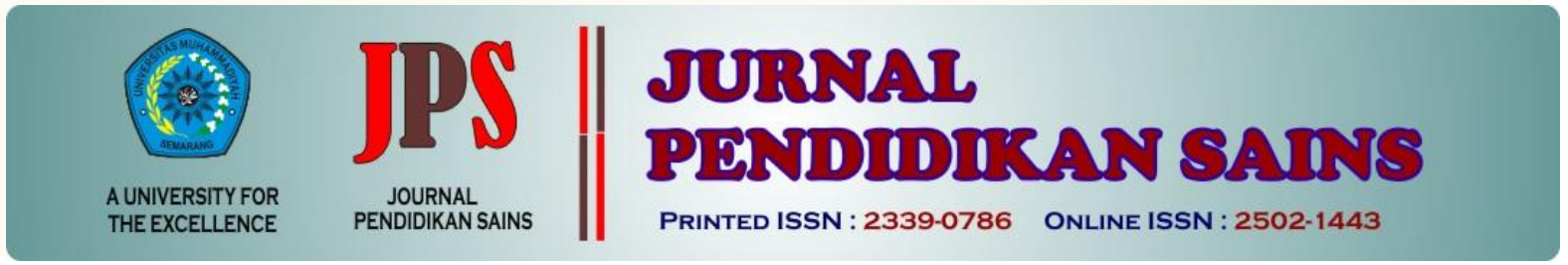

http://jurnal.unimus.ac.id/index.php/JPKIMIA

\title{
PENERAPAN PRAKTIKUM JARAK JAUH PADA TOPIK PERTUMBUHAN MIKROBA DALAM MASA DARURAT COVID-19 DI INSTITUT TEKNOLOGI SUMATERA
}

\author{
Oleh: \\ Fina Khaerunnisa Frima ${ }^{1}$, Sysi Novita ${ }^{1}$, M. Rofif Nurfaizi ${ }^{1}$, Riyanto Widodo ${ }^{1}$, M. Husen ${ }^{1}$ \\ ${ }^{1}$ Kimia, Institut Teknologi Sumatera
}

\begin{tabular}{ll}
\hline \multicolumn{2}{l}{ Article history } \\
\hline Submission & $: 2020-06-13$ \\
Revised & $: 2020-07-07$ \\
Accepted & $: 2020-07-14$
\end{tabular}

Keyword:

Kata kunci: praktikum jarak jauh, biokimia,

pertumbuhan mikroba

\begin{abstract}
Institut Teknologi Sumatera ordered the implementation of distance learning method by accessing the online courses since $18^{\text {th }}$ March 2020 to $29^{\text {th }}$ May 2020. One of the obstacle for implementation the distance learning in Departement of Chemistry is the achievement of practical skill competencies. This study describes the implementation of laboratory practice in home at one of biochemistry topic using daily chemical and been adjusted with Department of Chemistry learning outcomes and curriculum. Design of this study is one-shot case study and subjects were the 92 of second year college students at Department of Chemistry, Institut Teknologi Sumatera. Instruments of this study are quesioner guideline and student practicum report. The result of implementation the alternative laboratory practice in home were $71.7 \%$ of students well-understood the instruction in handbook, $91.3 \%$ of students agreed that the topic of distance laboratory practice been accordance with the curriculum, and $80.4 \%$ of students were able to elaborate other useful topic of implementation laboratory practice in daily life. Around $83 \%$ of students could make the good practicum report. Implementation of chemistry laboratory practice using daily chemical in home could be considered as one of distance laboratory practice to achieve the practical skill competencies.
\end{abstract}

\section{Pendahuluan}

Coronavirus Disease (COVID-19) disebabkan oleh virus Severe Acute Respiratory Syndrome Coronavirus-2 (SARS-Cov-2) adalah penyakit yang menyebabkan pandemik dengan tingkat penularan yang cepat, tingkat mortalitas tinggi dan belum adanya terapi definit (Susilo, dkk, 2020). Tercatat sampai dengan tanggal 10 Juni 2020, jumlah kasus COVID-19 di dunia adalah 7.318.124, angka kematian adalah 413.648, dan angka pasien sembuh sebanyak
3.602.580. Jumlah kasus COVID-19 di Indonesia yaitu 33.076, angka kematian adalah 1.923, dan angka pasien sembuh sebanyak 11.414 (www.worldometers.info.coronavirus/, 10 Juni 2020). Upaya Pemerintah Indonesia dalam mencegah meluasnya penularan COVID19 terutama di Lingkungan Kementerian Pendidikan dan Kebudayaan menerbitkan beberapa arahan mengenai proses belajar dari rumah (Arifa, 2020). Berdasarkan Surat Edaran Menteri Pendidikan dan Kebudayaan Republik Indonesia Nomor 36962/MPK.A/HK/2020

*Corresponding Author:

$\begin{array}{ll}\text { Nama } & \text { : Fina Khaerunnisa Frima } \\ \text { Lembaga } & \text { : Institut Teknologi Sumatera } \\ \text { Email } & \text { : fina.khaerunissa@ki.itera.ac.id }\end{array}$


tanggal 17 Maret 2020 memberlakukan pelaksanaan pembelajaran dalam jaringan (Daring) dari rumah bagi siswa dan mahasiswa (Mendikbud, 2020). Pembelajaran daring dilaksanakan dari tingkat sekolah dasar hingga perguruan tinggi.

Institut Teknologi Sumatera mewajibkan pelaksanaan pembelajaran jarak jauh dengan melakukan perkuliahan Daring selama masa darurat COVID-19 dari tanggal 18 Maret 2020 sampai 29 Mei 2020. Dalam proses pelaksanaan pembelajaran jarak jauh, Institut Teknologi Sumatera memiliki e-learning yang dapat diakses oleh khususnya mahasiswa Program Studi Kimia di laman kuliah.itera.ac.id. Mahasiswa dapat mengunduh materi presentasi dosen dan textbook sebagai literatur utama, mengerjakan tugas, kuis, dan ujian melalui laman e-learning sesuai dengan mata kuliah yang dipelajari. Program Studi Kimia tetap melaksanakan kegiatan penyampaian dan diskusi materi perkuliahan dengan menggunakan aplikasi Google Meet pada jam perkuliahan dalam upaya melaksanakan pembelajaran jarak jauh dalam masa darurat COVID-19.

Pembelajaran jarak jauh dalam perkuliahan adalah pelaksanaan pembelajaran ketika mahasiswa dan dosen tidak dapat hadir tatap muka pada waktu bersamaan di ruang kuliah kampus. Salah satu upaya pelaksanaan pembelajaran jarak jauh adalah dengan menggunakan kegiatan literasi interaktif yang pernah diuji cobakan pelaksanaannya di tingkat sekolah dasar (Setiawan, 2020). Pembelajaran jarak jauh bukanlah hal baru bagi dunia pendidikan kimia, namun membutuhkan dedikasi dan inisiatif lebih dibanding pelaksanaan pendidikan konvensional (Casanova, et. al, 2006).

Pelaksanaan pembelajaran jarak jauh berupa praktikum jarak jauh bagi Program Studi Kimia terhitung sulit untuk dilaksanakan terutama dalam pencapaian kompetensi keahlian praktikum. Kesulitan yang didapatkan ketika melaksanakan praktikum jarak jauh adalah resiko bahaya dalam menggunakan bahan kimia di rumah, resiko pengiriman bahan kimia agar tidak mengalami kebocoran, dan resiko penambahan biaya pengiriman bahan kimia yang dibebankan kepada mahasiswa (McCalmont, 2013). Selain itu, permasalahan terkait pelaksanaan praktikum jarak jauh yaitu tidak dapat terciptanya atmosfer laboratorium dikarenakan tidak didapatkan teknik dan keahlian laboratorium yang nyata dalam melaksanakan percobaan untuk mendapatkan data kuantitatif yang presisi (Casanova, et. al, 2006).

Tiga cara penyelesaian efektif terhadap permasalahan pelaksanaan praktikum jarak jauh yaitu dengan melaksanakan praktikum, melalui: (1) virtual laboratorium, (2) video praktikum, dan (3) kitchen chemistry experiment. Mahasiswa dapat melaksanakan praktikum secara virtual dengan menggunakan komputer pada berbagai platform virtual laboratorium yang tersedia, seperti pada Second Life (SL) yang dikembangkan oleh Linden Lab. Mahasiswa dapat melaksanakan virtual praktikum di SL, berupa: PCR (polymerase chain reaction), visualisasi tiga dimensi struktur biomolekul kompleks, dan titrasi. Hasil penelitian menunjukkan bahwa tidak adanya perbedaan hasil prestest, posttest, dan nilai laporan praktikum antara mahasiswa yang melaksanakan praktikum di laboratorium dan virtual laboratorium (Winkelmann, et. al, 2017). Platform virtual laboratorium kimia lainnya yaitu ChemVLab+ (Davenport, et. al, 2018). Media sosial seperti iTube, YouTube, dan WeTube dapat dijadikan sebagai platform untuk mempelajari berbagai video praktikum kimia yang dibuat oleh publik. Keterlibatan publik luas dalam penggunaan media sosial yang bijak dapat dijadikan peranan penting dalam menjaga perkembangan ilmu kimia agar dapat menurunkan jumlah chemophobia (Smith, 2014).

Pada dasarnya, kitchen chemistry experiment adalah pelaksanaan praktikum kimia di rumah yang tidak lebih berbahaya dibanding dengan kegiatan memasak. Alat dan bahan yang digunakan, tidak berbahaya dan dapat dibeli di toko atau pasar lokal (Casanova, et. al, 2006). Pelaksanaan praktikum kimia di rumah dikembangkan dengan tujuan agar mahasiswa dapat mewujudkan pengalaman kimia dimanapun dan kapanpun sesuai dengan program AACE (anywhere, anytime chemistry experience). Kitchen chemistry experiment melibatkan mahasiswa untuk dapat menggali dan menggunakan pengetahuan dan kemampuan dalam menjawab permasalahan dalam kehidupan sehari hari yang berkaitan dengan ilmu kimia. Praktikum memiliki peranan untuk dapat mengembangkan keterampilan berpikir kritis mahasiswa (Rosa \& Nursa'adah, 2017). Keterampilan berpikir kritis yang dapat dilatih dengan menggunakan metode pembelajaran praktikum, yaitu: keterampilan mengungkapkan masalah, 
mengemukakan hipotesis, merancang eksperimen, membuat pertimbangan, memberikan alasan dan mengemukakan kesimpulan. Hasil penelitian sebelumnya mengenai keterampilan berpikir kritis pada salah satu materi kimia menunjukkan hasil tergolong baik melalui metode pembelajaran yaitu praktikum kimia (Frima, dkk, 2020).

Penelitian ini bertujuan untuk mengembangkan dan menerapkan praktikum jarak jauh pada salah satu topik mata kuliah Dasar-Dasar Kimia Hayati yang dipelajari oleh mahasiswa semester IV di Program Studi Kimia, Institut Teknologi Sumatera. Penerapan praktikum jarak jauh pada topik 'Pertumbuhan Mikroba' ini dapat dijadikan sebagai alternatif pencapaian kompetensi keahlian praktikum mahasiswa Program Studi Kimia dalam masa darurat COVID-19.

Alternatif pelaksanaan praktikum dalam penelitian adalah penyesuaian materi, alat dan bahan dengan daily chemical, dikarenakan keterbatasan alat dan bahan praktikum jika dikirimkan ke seluruh mahasiswa Program Studi Kimia Institut Teknologi Sumatera yang tersebar di pulau Jawa dan Sumatera. Selain itu, alternatif praktikum dilakukan sebagai bentuk tanggung jawab Program Studi Kimia Institut Teknologi Sumatera dalam upaya pencapaian kompetensi praktikum dasar yang harus dikuasai oleh mahasiswa ketika dinyatakan lulus dari mata kuliah Dasar-Dasar Kimia Hayati.

\section{Metode Penelitian}

\section{Jenis Penelitian}

Jenis penelitian adalah penelitian kuantitatif dengan desain penelitian adalah onecase study, yaitu mengolah data kuesioner mengenai pelaksanaan praktikum jarak jauh pada topik pertumbuhan mikroba dengan menggunakan daily chemical.

\section{Waktu dan Tempat Penelitian}

Penelitian dilaksanakan di Program Studi Kimia, Jurusan Sains, Institut Teknologi Sumatera pada semester genap tahun akademik 2019/2020. Waktu penelitian dilaksanakan pada bulan April 2020 - Mei 2020 selama penerapan pelaksanaan pembelajaran jarak jauh dalam masa darurat COVID-19 pada mata kuliah Dasar-Dasar Kimia Hayati.

\section{Subjek Penelitian}

Subjek penelitian adalah mahasiswa angkatan 2018 (tahun kedua perkuliahan)
Program Studi Kimia, Jurusan Sains, Institut Teknologi Sumatera, sebanyak 92 mahasiswa. Dalam pelaksanaan praktikum jarak jauh, mahasiswa dikelompokkan menjadi enam (6) kelompok berdasarkan kemudahan memperoleh bahan kimia di lingkungan sekitar rumah, yaitu: (1) pembersih lantai (wipol), (2) sabun cuci piring (sunlight), (3) rinso, (4) handsanitizer, (5) sabun mandi (dettol), dan (6) bahan alam (daun sirih). Satu kelompok praktikum terdiri dari 5 mahasiswa.

\section{Prosedur}

Penelitian berlangsung melalui tiga tahapan, yaitu: tahap persiapan praktikum, pelaksanaan praktikum, dan evaluasi pelaksanaan. Tahap persiapan praktikum meliputi: analisis capaian mata kuliah DasarDasar Kimia Hayati, studi literatur mengenai kesesuaian materi praktikum yaitu pengaruh pemberian jenis desinfektan terhadap pertumbuhan mikroba. Tahap persiapan dilanjutkan dengan perbaikan modul praktikum pertumbuhan mikroba yang disesuaikan antara capaian mata kuliah Dasar-Dasar Kimia Hayati dengan kesesuaian alat dan bahan yang dapat dicari di toko atau pasar di lingkungan rumah mahasiswa. Perbaikan modul dilakukan dan dikembangkan oleh tim dosen kelompok keahlian Biokimia, Program Studi Kimia, Institut Teknologi Sumatera.

Tahap pelaksanaan praktikum meliputi: (1) pembagian kelompok mahasiswa, (2) pembagian modul praktikum pertumbuhan yang telah disesuaikan, (3) kegiatan tatap muka daring melalui Google Meet untuk memberikan demonstrasi praktikum yang akan dilaksanakan dan diskusi pelaksanaan praktikum, (4) video demonstrasi diunggah dalam laman youtube dengan judul 'Praktikum DDKH: Pertumbuhan Mikroba dari Udara', dan (5) mahasiswa melaksanakan praktikum secara mandiri dalam kelompok dengan menggunakan alat dan bahan yang sama oleh tiap anggota. Kemudian dilakukan tahapan evaluasi terhadap pelaksanaan praktikum jarak jauh dengan menggunakan dua instrumen penelitian, yaitu: pedoman kuesioner dan laporan praktikum mahasiswa.

\section{Instrumen}

Instrumen yang digunakan dalam penelitian ini berupa pedoman kuesioner dan laporan praktikum mahasiswa. Pedoman kuesioner terbagi ke dalam tiga kelompok evaluasi. Kelompok kuesioner pertama adalah 
evaluasi persiapan praktikum jarak jauh, meliputi: (1) pemahaman bahasa dalam modul praktikum, (2) pemahaman tujuan praktikum dalam modul, (3) pemahaman langkah kerja praktikum dalam modul, (4) pemahaman langkah kerja praktikum setelah demonstrasi, (5) kesesuaian materi praktikum dengan materi pembelajaran. Kelompok kuesioner kedua adalah evaluasi terhadap ketercapaian kompetensi keahlian praktikum, meliputi: (1) menyusun teori pendukung, (2) memahami fungsi alat dan bahan yang digunakan, (3) melaksanakan praktikum mandiri, (4) menjaga keselamatan kerja, (5) observasi hasil praktikum: observasi pengaruh perbedaan konsentrasi desinfektan terhadap pertumbuhan mikroba, kontrol negatif, dan kontrol positif, (6) menuliskan hasil pengamatan dalam bentuk grafik, dan (7) menarik kesimpulan. Kelompok kuesioner ketiga adalah pesan dan kesan yang dirasakan mahasiswa ketika melaksanakan kitchen chemistry experiment dalam upaya pengembangan terhadap implementasi, meliputi: (1) mudah dan praktis, (2) manajemen waktu, (3) tidak terbebani, (4) alat dan bahan mudah dicari, (5) keaktifan diskusi kelompok, (5) curiousity of daily science, (6) elaborasi ide praktikum biokimia dalam kehidupan seharihari, dan (7) ide baru setelah pelaksanaan praktikum di rumah. Laporan praktikum dinilai berdasarkan komponen penilaian praktikum Program Studi Kimia, Institut Teknologi Sumatera.

\section{Teknik Analisis Data}

Berikut adalah langkah-langkah yang dilakukan dalam menganalisis data hasil penelitian:

\section{Kuesioner}

Hasil kuesioner dianalisis untuk deskripsi terhadap evaluasi pengembangan dan pelaksanaan praktikum jarak jauh pada topik pertumbuhan mikroba dalam masa darurat COVID-19 di Program Studi Kimia, Institut Teknologi Sumatera.

\section{Laporan Praktikum}

a) Memberikan total skor pada setiap laporan praktikum mahasiswa.

b) Menghitung jumlah sebaran nilai yang diperoleh mahasiswa dalam masingmasing kategori jawaban (tinggi dan sedang).

c) Mendeskripsikan data penelitian.

\section{Hasil Penelitian dan Pembahasan}

Data penelitian berupa hasil kuesioner mahasiswa terhadap evaluasi pelaksanaan praktikum jarak jauh pada topik pertumbuhan mikroba dalam masa darurat COVID-19 di Program Studi Kimia, Institut Teknologi Sumatera. Data kuesioner mahasiswa meliputi data: (1) persiapan praktikum, (2) kompetensi keahlian praktikum, (3) pelaksanaan, dan (4) sebaran nilai laporan praktikum mahasiswa pada kategori jawaban (tinggi dan sedang) pada tabel 1.

\section{Evaluasi Persiapan Praktikum}

Program Studi Kimia Institut Teknologi Sumatera melaksanakan praktikum jarak jauh dengan metode kitchen chemistry experiment pertama kalinya pada topik pertumbuhan mikroba dalam masa darurat COVID-19. Modul praktikum jarak jauh dengan topik pertumbuhan mikroba telah disesuaikan dengan capaian mata kuliah DasarDasar Kimia Hayati pada sub bab, yaitu: tipe jenis sel dan teknik analisis sel. Hal ini diperkuat dengan hasil evaluasi oleh mahasiswa yaitu sebanyak 91,3\% mahasiswa setuju bahwa materi praktikum pertumbuhan mikroba telah sesuai dengan materi pembelajaran di kelas. Alat dan bahan kimia yang digunakan dalam modul praktikum telah disesuaikan ketersediannya dengan seluruh mahasiswa, sehingga setiap anggota dalam kelompok memiliki alat dan bahan yang sama sesuai dengan pembagian kelompok. Selanjutnya modul diperiksa kelayakan pelaksanaan oleh Dosen Pembina Program Studi Institut Teknologi Sumatera, yaitu Dosen dari Jurusan Kimia, Institut Teknologi Bandung.

Berdasarkan evaluasi dalam kuesioner pada 92 mahasiswa pada persiapan pelaksanaan praktikum, sebanyak 96,7\% mahasiswa memahami bahasa di modul praktikum pertumbuhan mikroba, dikarenakan penulisan modul praktikum menggunakan Bahasa Indonesia dan tidak menggunakan istilah bahasa asing. Hal ini sesuai dengan Wusqo (2016) bahwa mahasiswa cenderung tidak dapat memahami modul praktikum karena banyaknya penggunaan istilah dalam bahasa asing, sehingga terjadi kesalahan tafsir dan membutuhkan waktu yang lama untuk dapat mengerti modul praktikum.

Semua mahasiswa memahami tujuan praktikum dalam modul praktikum pertumbuhan mikroba. Hanya terdapat $71,7 \%$ dari jumlah mahasiswa yang telah memahami 
langkah kerja dalam modul praktikum pertumbuhan mikroba. Sehingga, perlu dilaksanakan kegiatan tatap muka daring melalui Google Meet agar seluruh mahasiswa menggunakan alat, bahan, jumlah, ukuran yang sama, dan demonstrasi langkah kerja praktikum. Demonstrasi praktikum diberikan oleh dosen pengampu meliputi langkah kerja persiapan sterilisasi, langkah sterilisasi alat dan bahan sederhana di rumah, teknik penangkapan bakteri dari udara rumah, dan pengamatan mikroba yang tumbuh dalam media pertumbuhan. Setelah dilaksanakan demonstrasi praktikum, sebanyak 98,9 \% mahasiswa telah memahami langkah kerja praktikum yang harus dilaksanakan. Guna meminimalisasi kesalahan langkah kerja yang dilaksanakan, maka video demonstrasi diunggah pada laman youtube dengan judul 'Praktikum DDKH: Pertumbuhan Mikroba dari Udara'. Hal tersebut sejalan dengan yang diungkapkan Turkoguz (2012), bahwa video demonstrasi praktikum yang direkam dan diunggah pada media sosial dapat memberikan kontribusi positif terhadap sikap dan keahlian siswa dalam melaksanakan praktikum.

\section{Evaluasi Kompetensi Keahlian Praktikum}

Kompetensi praktikum dasar yang harus dimiliki mahasiswa setelah melaksanakan praktikum pertumbuhan mikroba, yaitu: (1) menyusun teori pendukung, (2) memahami fungsi alat dan bahan yang digunakan, (3) melaksanakan praktikum mandiri, (4) menjaga keselamatan kerja, (5) melakukan observasi hasil praktikum. Hasil evaluasi menunjukkan 93\% mahasiswa mampu menyusun landasan teori yang berhubungan dengan pelaksanaan praktikum pertumbuhan mikroba. Seluruh mahasiswa memahami dasar penggunaan alat dan bahan dalam digunakan dalam praktikum, seperti: daily utensil (gelas, plastik, sendok, kukusan/steamer, kertas, tissue, dan jenis desinfektan). Hal ini menunjukkan bahwa mahasiswa telah membaca, mengerti, dan menghubungkan teori dengan langkah kerja dalam pelaksanaan praktikum, sehingga dapat mempermudah melaksanakan praktikum. Sesuai menurut Frima (2020) bahwa salah satu kesulitan siswa dalam melaksanakan praktikum yaitu kurangnya usaha siswa dalam membaca teori.

Mahasiswa telah membaca sebelum melaksanakan praktikum dibuktikan dengan hasil evaluasi yang menunjukkan 95\% mahasiswa mampu melaksanakan praktikum secara mandiri dalam kelompok. Dalam melaksanakan pratikum pertumbuhan mikroba, berikut adalah kompetensi praktikum yang dicapai mahasiswa, yaitu: persiapan sterilisasi, sterilisasi sederhana di rumah dengan teknik kukus, teknik penumbuhan bakteri dari udara rumah (perbedaan teknik untuk kontrol negatif, kontrol positif, dan perbedaan konsentrasi desinfektan yang dipakai), dan pengamatan jenis mikroba yang tumbuh dalam media pertumbuhan agar. Walaupun praktikum dilakukan di rumah dengan peralatan sederhana, namun resiko bahaya tetap ada karena menggunakan kompor atau api untuk sterilisasi. Hasil evaluasi menunjukkan semua mahasiswa mampu melaksanakan praktikum dengan tetap mengutamakan keselamatan kerja. Pada dasarnya menurut McCalmont (2013), praktikum jarak jauh harus dirancang agar tidak berbahaya dalam untuk dapat dilaksanakan di rumah.

Hasil evaluasi praktikum di rumah menunjukan $88 \%$ mahasiswa mampu melakukan observasi hasil praktikum, yaitu: observasi pengaruh perbedaan konsentrasi desinfektan terhadap pertumbuhan mikroba, kontrol negatif, dan kontrol positif. Sebanyak 84\% mahasiswa mampu menuliskan data praktikum, dan 96\% mahasiswa dapat menuliskan kesimpulan praktikum. Kemampuan melakukan observasi, menuliskan data praktikum dan kesimpulan merupakan keterampilan berpikir kritis yang dapat dikembangkan melalui pelaksanaan praktikum. Hal ini sesuai dengan yang diungkapkan Rosa dan Nursa'adah (2017), bahwa pembelajaran dengan metode praktikum mengharuskan siswa untuk aktif dalam mengembangkan keterampilan berpikir kritis untuk pemecahan masalah melalui identifikasi persamaan dan perbedaan data praktikum agar dapat ditemukan jawaban yang dituliskan dalam bentuk kesimpulan.

\section{Evaluasi Pelaksanaan Praktikum}

Sebanyak $86 \%$ mahasiswa merasa pelaksanaan praktikum di rumah lebih mudah dan praktis dibanding pelaksanaan praktikum di laboratorium. Hasil evaluasi sejumlah $88 \%$ mahasiswa dapat mengerjakan praktikum tepat waktu selama 1 minggu. Terdapat $85 \%$ mahasiswa merasa senang dapat melaksanakan praktikum di rumah. Alat dan bahan praktikum dapat dicari dengan mudah di lingkungan sekitar rumah yang dirasakan sejumlah $85 \%$ mahasiswa. Hasil evaluasi menunjukkan 
sebanyak 92\% mahasiswa merasa diskusi kelompok selama pelaksanaan praktikum tetap aktif. Sejumlah 91\% mahasiswa merasa bertumbuh sikap curiousity of daily science setelah dilaksanakan praktikum di rumah. Hasil evaluasi yaitu $80,4 \%$ mahasiswa mampu elaborasi ide praktikum biokimia dalam kehidupan sehari-hari, dan beberapa mahasiswa pun mampu memberikan ide baru praktikum biokimia dalam kehidupan sehari-hari setelah melaksanakan praktikum di rumah.

Munculnya ide baru tersebut menunjukkan bahwa alternatif pelaksanaan kitchen chemistry experiment pada penelitian ini telah sesuai dengan tujuan pembelajaran abad 21 menurut Bell (2010), yaitu untuk melatih skill for the future dalam mencetak masyarakat produktif. Pelaksanaan praktikum dalam penelitian ini dapat dijadikan salah satu alternatif pembelajaran yang dapat melatih keterampilan berpikir kreatif menurut Filsaime (2008), yang ditunjukan dengan proses berpikir dengan salah satu cirinya yaitu elaborasi sehingga dapat memuculkan ide atau gagasan dalam memecahkan masalah dengan prinsip kebaruan.

\section{Penilaian Laporan Praktikum}

Laporan praktikum mahasiswa dinilai berdasarkan keterkaiatan pembahasan laporan praktikum dengan: (1) tujuan praktikum, (2) data praktikum, dan (3) materi perkuliahan. Hasil penilaian laporan praktikum dapat dilihat pada Tabel 1. Pengelompokan mahasiswa didasarkan pada nilai laporan praktikum, yaitu: tinggi dan sedang. Kelompok tinggi adalah mahasiswa yang memiliki nilai laporan praktikum 80-100, sedangkan kelompok sedang adalah mahasiswa dengan nilai laporan praktikum 65-79. Nilai laporan praktikum mahasiswa tidak ada yang kurang dari 65 .

Tabel 1.

Kelompok Nilai Laporan

\begin{tabular}{cc}
\hline Nilai Kelompok & $\begin{array}{c}\text { Jumlah } \\
\text { Mahasiwa (\%) }\end{array}$ \\
\hline Tinggi & $83 \%$ \\
\hline Sedang & $13 \%$ \\
\hline
\end{tabular}

Banyaknya mahasiswa yang masuk ke dalam kategori nilai tinggi menunjukkan bahwa sejumlah $83 \%$ mahasiswa telah memahami materi perkuliahan melalui pelaksanaan praktikum. Hal ini sejalan dengan Salirawati dalam Rosa dan Nursa'adah (2017), bahwa pemahaman siswa secara utuh dan komprehensif terhadap materi tidak terlepas dari pemanfaatan laboratorium dengan melaksanakan praktikum sebagai upaya dukungan agar tercapainya keberhasilan pembelajaran kimia.

\section{Simpulan dan Saran}

\section{Simpulan}

Permasalahan pembelajaran daring dalam masa darurat COVID-19 di Program Studi Kimia adalah ketercapaian keterampilan praktikum bagi mahasiswa dikarenakan tidak terlaksanannya kegiatan praktikum di laboratorium. Hal tersebut dapat diatasi dengan pelaksanaan praktikum jarak jauh dengan metode kitchen chemistry experiment pada topik pertumbuhan mikroba. Kompetensi praktikum mahasiswa dapat dimiliki setelah melaksanakan praktikum pertumbuhan mikroba, yaitu: (1) menyusun teori pendukung, (2) memahami fungsi alat dan bahan yang digunakan, (3) melaksanakan praktikum mandiri, (4) menjaga keselamatan kerja, (5) melakukan observasi hasil praktikum, semuanya memiliki nilai hasil evaluasi lebih dari $80 \%$. Hasil evaluasi menunjukkan bahwa mahasiswa mampu melatih keterampilan praktikum melalui pelaksanaan praktikum jarak jauh di rumah dengan menggunakan daily chemical.

\section{Saran}

Pelaksanaan praktikum jarak jauh dengan menggunakan daily chemical dapat dijadikan sebagai salah satu upaya pencapaian kompetensi praktikum selain pada masa darurat COVID-19, melainkan untuk kampus atau universitas yang memiliki keterbatasan alat dan bahan dalam melaksanakan praktikum konvensional.

\section{Ucapan Terima Kasih}

Ucapan terimakasih disampaikan pada Prof. Fida Madayanti Warganegara, MS, Ph.D Dosen Jurusan Kimia Institut Teknologi Bandung selaku Dosen Pembina Program Studi Kimia Institut Teknologi Sumatera. Penulis mengucapkan terimakasih pada seluruh tim dosen dan mahasiswa Program Studi Kimia, Jurusan Sains, Institut Teknologi Sumatera. 


\section{Daftar Pustaka}

Arifa, N.F. (2020). Tantangan Pelaksanaan Kebijakan Belajar dari Rumah dalam Masa Darurat COVID-19. Info Singkat Pusat Penelitian Badan Keahlian DPR RI, 12(7), 13-18.

Bell, Stephanie. (2010). Project-Based Learning for the $21^{\text {st }}$ Century: Skills for the Future. The Clearing House, 83(2), 3943.

https://doi.org/10.1080/0009865090350 5415

Casanova, R. S., Civelli, J. L., Kimbrough, D. R., Heath, B. P., \& Reeves, J. H. (2006). Distance learning: A viable alternative to the conventional lecturelab format in general chemistry. Journal of Chemical Education, 83(3), 501-507. https://doi.org/10.1021/ed083p501

Davenport, J. L., Rafferty, A. N., \& Yaron, D. J. (2018). Whether and How Authentic Contexts Using a Virtual Chemistry Lab Support Learning. Journal of Chemical Education, 95(8), 12501259.

https://doi.org/10.1021/acs.jchemed.8b 00048

Filsaime, D. K. (2008). Menguak Rahasia Berpikir Kritis dan Kreatif. Jakarta: Prestasi Pustaka.

Frima, F. K., Gumilar, G. G., Supriyanti, FM. T. (2020). Pengaruh Metode DiscoveryInquiry terhadap Profil Keterampilan Berpikir Kritis Siswa pada Pembelajaran Topik Kelarutan, Jurnal Pendidikan Sains, 8(1), 41-49. https://doi.org/10.26714/jps.8.1.2020.4 $1-49$

McCalmont, W. F. (2013). The Feasibility of Distance Learning with the Traditional Laboratory-Based Chemistry Class. Tesis, tidak dipublikasikan. Center for Teaching Excellence, United States Military Academy.

Menteri Pendidikan dan Kebudayaan Republik Indonesia (2020). Pembelajaran secara Daring dan Bekerja dari Rumah dalam Rangka Pencegahan Penyebaran
Corona virus Disease (COBID-19). Diakses tanggal 5 Juni 2020 dari http://ldikti14.ristekdikti.go.id.

Rosa, N. M. \& Nursa'adah, F. P. (2017). Kontribusi Laboratorium Kimia dan Sikap Siswa terhadap Pemanfaatan Laboratorium terhadap Keterampilan Berpikir Kritis dan Kreatif. Jurnal Formatif, 7(3), 198-206. http://dx.doi.org/10.30998/formatif.v7i 3.2230

Setiawan, A. R. (2020). Lembar Kegiatan Literasi Saintifik untuk Pembelajaran Jarak Jauh Topik Penyakit Coronavirus 2019 (COVID-19). EDUKATIF: Jurnal Ilmu Pendidikan, 2(1), 28-37. https://doi.org/10.31004/edukatif.v2i1.8 0

Smith, D. K. (2014). iTube, YouTube, WeTube: Social Media Videos in Chemistry Education and Outreach. Journal of Chemical Education, 91(10), 1594-1599.

https://doi.org/10.1021/ed400715s

Susilo, A., Rumende, C. M., Pitoyo, C. W., Santoso, W. D., Yulianti, M., Herikurniawan., Sinto, R., Singh, G., Nainggolan, L., Nelwan, E. J., Chen, L. K., Widhani, A. Wijawa, E., Wicaksana, B., Maksum, M., Annisa, F., Jasirwani, OM. C., Yunihastuti, E. (2020). Coronavirus Disease 2019: Tinjauan Literatur Terkini. Jurnal Penyakit Dalam Indonesia, 7(1), 45-67. http://dx.doi.org/10.7454/jpdi.v7i1.415

Turkoguz, Suat. (2012). Learn to Teach Chemistry using Visual Media Tools. Chemistry Education Research and Practice, 13, 401-409. https://doi.org/10.1039/C2RP20046E

Winkelmann, K., Keeney-Kennicutt, W., Fowler, D., \& Macik, M. (2017). Development, Implementation, and Assessment of General Chemistry Lab Experiments Performed in the Virtual World of Second Life. Journal of Chemical Education, 94(7), 849-858. https://doi.org/10.1021/acs.jchemed.6b 00733 
Wusqo, I. U., Taufiq, M., \& Handayani, R. (2016). Pengembangan Asesmen Alternatif Praktikum Kimia Dasar Ii Melalui Chemistry Fair Project (Cfp) Berbasis Konservasi Dengan Memanfaatkan Daily Chemical. Jurnal Penelitian Pendidikan, 33(2), 145-154. DOI: 10.15294/jpp.v33i2.9096 